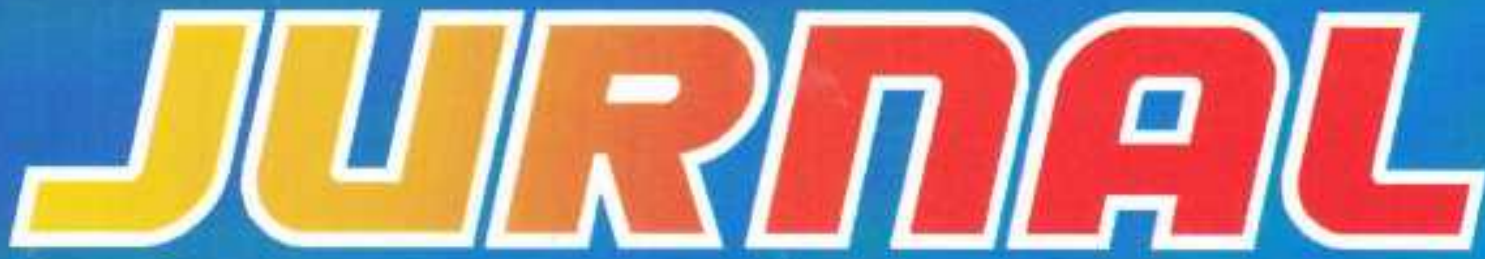

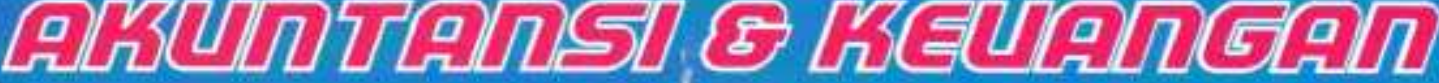

Volume 6, No. 1, Maret 2015

ISSN: $2087-2054$

Pengaruh Peran Acoount Representative Terhadap Tingkat Kepatuhan Wajib Pajak (Studi kasus pada KPP Pratama di Kota Bandar Lampung)

\section{Angrita Denziana \& Handi Sutanto}

Pengaruh Biaya Iklan Dan Biaya Penjualan Personal Terhadap Nilai Penjualan Pada PT Telekomunikasi Indonesia, Tbk.

\section{Chairul Anwar \& Rinna}

Relationship Executives Rewards With Financial Performance On Corporate Banking In Indonesia

\section{Haninun \& Putri Cagora Nisa}

Analisis Penerapan Metode Pengakuan Pendapatan Terhadap Laba Perusahaan Pada Pt. Coca Cola Distribusi Indonesia (Cabang Tanjung Karang)

\section{Herry Goenawan Soedarsa \& Surya Pandelima}

Pengaruh Tingkat Suku Bunga Simpanan Terhadap Jumlah Deposito Pada Pt. Bank Rakyat Indonesia (Persero) Tbk. Cabang Liwa

\section{Indrayenti \& Susanti}

Pengaruh Motivasi Terhadap Minat Mahasiswa Akuntansi Untuk Mengikuti Pendidikan Profesi Akuntansi (PPAK) Di Provinsi Lampung

\section{Rosmiaty Tarmizi \& Julia Restuti}

Pengaruh Kinerja Hutang Terhadap Nilai Perusahaan Pada Perusahaan Pertambangan Batubara Yang Terdaftar Di Bei Periode 2010-2013

\section{Khairudin \& Rico Tanto}

Pengaruh Profitabilitas, Ukuran Perusahaan, Debt To Equity Terhadap Ketepatan Waktu Penyampaian Laporan Keuangan (Studi Pada Perusahaan Asuransi Yang Terdaftar Di BEI)

\section{Riswan \& Tri Lestari Saputri}

Pengaruh Manajemen Laba Terhadap Kinerja Keuangan Pada Perusahaam Manufaktur Tahun 2011-2012

\section{Aminah \& Lidya Natasia Gunakan}




\section{Dewan Pembina}

Dr. Ir. M. Yusuf S. Barusman, M.B.A

Dr. Andala Rama Putra Barusman, S.E., M.A.Ec.

\section{Penanggung Jawab}

Dra. Rosmiaty Tarmizi, M.M.Akt. C.A

\section{Pimpinan Redaksi}

Dr. Angrita Denziana, S.E., M.M, Ak. C.A

\section{Sekretaris Redaksi}

Aminah, S.E., M.S.Ak

Khairudin, S.E., M.S.Ak

\section{Penyuting Ahli}

Prof. Dr. Jogiyanto Hartono, M.B.A. ( Universitas Gadjah Mada)

Tina Miniawati, S.E., M.B.A. (Universitas Trisakti)

Dr. Khomsiyah, S.E., M.M. (Universitas Trisakti)

Dr. Lindrianasari, S.E., M.Si.Akt. (Universitas Lampung)

Sujoko Efferin, Mcom (Hons), MA(Econ), Ph.D. (Universitas Surabaya)

\section{Penerbit}

Universitas Bandar Lampung

Fakultas Ekonomi dan Bisnis Program Studi Akuntansi

SENARAI-Jurnal Akuntansi \& Keuangan Terbit 2 kali setahun pada bulan Maret \&

September

Artikel yang dimuat berupa hasil riset Empiris dan telaah teoritis konsepsual yang kritis dalam kajian bidang akuntansi, auditing, perpajakan, dan keuangan.

\section{Alamat Redaksi}

Gedung G- Program Studi Akuntansi Fakultas Ekonomi dan Bisnis Universitas Bandar Lampung

Kampus A Jalan Z.A Pagar Alam No. 26 Labuan Ratu Bandar Lampung 35142

Telp: (0721) 701979, Fax: (0721) 701467, Email: Prodi.akuntansi@ubl.ac.id 


\section{JURNAL \\ AKUNTANSI \& KEUANGAN}

Volume 6, No. 1, Maret 2015

ISSN: 2087-2054

Pengaruh Peran Acoount Representative Terhadap Tingkat Kepatuhan Wajib Pajak

(Studi Kasus pada KPP Pratama di Kota Bandar Lampung)

Angrita Denziana \& Handi Sutanto

Pengaruh Biaya Iklan dan Biaya Penjualan Personal Terhadap Nilai Penjualan Pada PT

Telekomunikasi Indonesia, Tbk.

\section{Chairul Anwar \& Rinna}

Relationship Executives Rewards With Financial Performance On Corporate Banking In Indonesia

\section{Haninun \& Putri Cagora Nisa}

Analisis Penerapan Metode Pengakuan Pendapatan Terhadap Laba Perusahaan Pada PT. Coca Cola Distribusi Indonesia (Cabang Tanjung Karang)

Herry Goenawan Soedarsa \& Surya Pandelima

Pengaruh Tingkat Suku Bunga Simpanan Terhadap Jumlah Deposito Pada PT. Bank Rakyat Indonesia (Persero) Tbk. Cabang Liwa

Indrayenti \& Susanti

Pengaruh Motivasi Terhadap Minat Mahasiswa Akuntansi Untuk Mengikuti Pendidikan Profesi Akuntansi (PPAK) Di Provinsi Lampung

\section{Rosmiaty Tarmizi \& Julia Restuti}

Pengaruh Kinerja Hutang Terhadap Nilai Perusahaan Pada Perusahaan Pertambangan Batubara Yang Terdaftar Di BEI Periode 2010-2013

\section{Khairudin \& Rico Tanto}

Pengaruh Profitabilitas, Ukuran Perusahaan, Debt To Equity Terhadap Ketepatan Waktu Penyampaian Laporan Keuangan (Studi Pada Perusahaan Asuransi Yang Terdaftar Di BEI) Riswan \& Tri Lestari Saputri

Pengaruh Manajemen Laba Terhadap Kinerja Keuangan Pada Perusahaam Manufaktur Tahun 2011-2012

\section{Aminah \& Lidya Natasia Gunakan}




\section{JURNAL \\ AKUNTANSI \& KEUANGAN}

Volume 6, No. 1, Maret 2015

ISSN: 2087-2054

Daftar Isi

Halaman

$1-22$

Pengaruh Peran Acoount Representative Terhadap Tingkat Kepatuhan

Wajib Pajak (Studi kasus pada KPP Pratama di Kota Bandar Lampung)

Angrita Denziana \& Handi Sutanto

Pengaruh Biaya Iklan Dan Biaya Penjualan Personal Terhadap Nilai

Penjualan Pada PT Telekomunikasi Indonesia, Tbk.

Chairul Anwar \& Rinna

Relationship Executives Rewards With Financial Performance On

Corporate Banking In Indonesia

Haninun \& Putri Cagora Nisa

Analisis Penerapan Metode Pengakuan Pendapatan Terhadap Laba

Perusahaan Pada PT. Coca Cola Distribusi Indonesia (Cabang Tanjung

Karang)

Herry Goenawan Soedarsa \& Surya Pandelima

Pengaruh Tingkat Suku Bunga Simpanan Terhadap Jumlah Deposito Pada

PT. Bank Rakyat Indonesia (Persero) Tbk. Cabang Liwa

Indrayenti \& Susanti

Pengaruh Motivasi Terhadap Minat Mahasiswa Akuntansi Untuk

Mengikuti Pendidikan Profesi Akuntansi (PPAK) Di Provinsi Lampung

Rosmiaty Tarmizi \& Julia Restuti

Pengaruh Kinerja Hutang Terhadap Nilai Perusahaan Pada Perusahaan

Pertambangan Batubara Yang Terdaftar Di BEI Periode 2010-2013

\section{Khairudin \& Rico Tanto}

Pengaruh Profitabilitas, Ukuran Perusahaan, Debt To Equity Terhadap

Ketepatan Waktu Penyampaian Laporan Keuangan (Studi Pada Perusahaan Asuransi Yang Terdaftar Di BEI)

Riswan \& Tri Lestari Saputri

Pengaruh Manajemen Laba Terhadap Kinerja Keuangan Pada Perusahaam Manufaktur Tahun 2011-2012

Aminah \& Lidya Natasia Gunakan 


\section{JURNAL AKUNTANSI \& KEUANGAN}

Volume 6, No. 1, Maret 2015

ISSN: $2087-2054$

\section{Informasi Kebijakan dan Selingkung Berkala}

\section{Kebijakan editorial}

JURNAL Akuntansi \& Keuangan adalah sebuah berkala yang dipublikasikan oleh Universitas Bandar Lampung, yang bertujuan untuk menjadi wadah kreatifitas para akademisi, profesional, peneliti, dan mahasiswa di bidang Akuntansi dan Keuangan termasuk juga bidang Auditing, Sistem Informasi Akuntansi, Tata kelola Perusahaan, Perpajakan, Akuntansi Internasional, Akuntansi Managemen, Akuntansi Keperilakuaan, Pasar Modal dan lain sebagainya. Topik yang semakin meluas di bidang kajian riset Akuntansi diakomodir publikasinya di dalam berkala ini.

Paper yang akan dipublikasikan di dalam berkala JURNAL Akuntansi \& Keuangan harus ditulis di dalam bahasa Indonesia yang baik dan sesuai dengan EYD. Semua instrumen yang digunakan untuk memperoleh data penelitian harus dimasukkan di dalam lampiran paper penelitian, paling tidak, penulis bersedia memberikan klarifikasi atas instrumen yang digunakan saat ada permintaan dari peneliti lainnya.

\section{Sekretariat Editor Berkala}

Gedung F - Fakultas Ekonomi Universitas Bandar Lampung

Fakultas Ekonomi Program Studi Akuntansi

Kampus A Jalan Z.A. Pagar Alam No. 26 Labuhan Ratu Bandar Lampung 35142

$$
\text { Telp.: (0721) 701979, Fax.: (0721) 701467, Email: }
$$

\section{Petunjuk penulisan}

Artikel yang dikirim ke JURNAL Akuntansi \& Keuangan harus mengikuti petunjuk seperti berikut:

1. Naskah merupakan naskah asli yang belum pernah diterbitkan atau sedang dilakukan penilaian pada berkala lain. Naskah ditulis dalam bahasa Indonesia dengan jarak 1 spasi, sepanjang 20-30 halaman kertas A4 dengan tipe huruf Times New Roman.. Naskah dikirim atau diserahkan ke sekretariat JURNAL Akuntansi \& Keuangan rangkap satu disertai disket berikut dengan biodata penulis dan alamat lengkap (kantor dan rumah) pada lembaran yang terpisah dari halaman pertama artikel.

2. Judul naskah dapat ditulis dengan menggambarkan isi pokok tulisan, dan atau ditulis secara ringkas, jelas, dan menarik. 
3. Nama Penulis disertai catatan kaki tentang profesi dan lembaga tempat penulis bekerja dalam naskah yang telah diterima untuk diterbutkan.

4. Abstrak ketik satu spasi, tidak lebih dari 250 kata dalam bahasa Inggris. Abstrak memuat tujuan penelitian, isu, permasalahan, sampel dan metode penelitian, serta hasil dan simpulan (jika memungkinan).

5. Pendahuluan beriksikan uraian tentang latar belakang masalah, ruang lingkup penelitian, dan telaah pustaka yang terkait dengan permasalahan yang dikaji, serta rumusan hipotesis (jika ada). Uraian pendahuluan maksimum $10 \%$ total halaman.

6. Untuk penelitian kuantitatif,

a. Telaah Literatur dan Pengembangan Hipotesis memuat paling tidak satu buah teori yang menjadi dasar pemikiran penelitian. Hipotesis dikembangkan menggunakan asumsi dasar teori dan hasil penelitian sebelumnya. Telah literatur maksimum $40 \%$ total halaman.

b. Metodologi Penelitian meliputi uraian yang rinci tentang bahan yang digunakan, metoda yang dipilih, teknik, dan cakupan penelitian. Uraian bahan dan metoda maksimum $20 \%$ total halaman.

7. Untuk penelitian kualitatif menyesuaikan dengan metodologi kualitatif.

8. Hasil dan Pembahasan merupakan uraian obyektif dari-hasil penelitian dan pembahasan dilakukan untuk memperkaya makna hasil penelitian. Uraian hasil dan pembahasan minimum $25 \%$ total halaman.

9. Simpulan yang merupakan rumusan dari hasil-hasil penelitian. Harus ada sajian dalam satu kalimat inti yang menjadi simpulan utama. Simpulan maksimum 10\% dari keseluruhan lembar artikel.

10. Referensi (Daftar Pustaka) ditulis berurutan berdasarkan alphabetical, disusun menggunakan suku kata terakhir dari nama penulisnya, atau institusi jika dikeluarkan oleh organisasi.

a. Buku: nama penulis, tahun penerbitan, judul lengkap buku, penyunting (jika ada), nama penerbit, dan kota penerbitan.

b. Artikel dalam buku: nama penulis, tahun penerbitan, judul artikel/tulisan, judul buku, nama penyunting, kota penerbitan, nama penerbit, dan halaman.

c. Terbitan berkala: nama penulis, tahun penerbitan, judul tulisan, judul terbitan (bila disingkat, sebaiknya menggunakan singkatan yang baku), volume, nomor, dan halaman.

d. Artikel dalam internet: nama penulis, judul, dan situsnya.

e. Tabel diberi nomor dan judul dilengkapi dengan sumber data yang ditulis dibawah badan tabel, diikuti tempat dan waktu pengambilan data.

f. Ilustrasi dapat berupa gambar, grafik, diagram, peta, dan foto diberi nomor dan judul.

11. Setiap referensi yang digunakan di dalam naskah artikel menggunakan petunjuk yang dirujuk pada The Indonesian Journal of Accounting Research, sebagai berikut:

A. Kutipan dalam tubuh naskah paper harus disesuaikan dengan contoh berikut:

I. Satu sumber kutipan dengan satu penulis (Brownell, 1981).

II. Satu sumber kutipan dengan dua penulis (Frucot dan Shearon, 1991).

III. Satu sumber kutipan dengan lebih dari satu penulis (Hotstede et al., 1990).

IV. Dua sumber kutipan dengan penulis yang berbeda (Dunk, 1990; Mia, 1988).

V. Dua sumber kutipan dengan satu penulis (Brownell, 1981, 1983).

VI. Dua sumber kutipan dengan satu penulis diterbitkan pada tahun yang sama (Brownell, 1982a, 1982b). 
VII. Sumber kutipan dari lembaga harus dinyatakan dengan menggunakan akronim institusi (FASB, 1994)

B. Setiap artikel harus menulis referensi menggunakan panduan berikut:

I. Referensi harus tercantum dalam urutan abjad dari nama belakang penulis atau nama lembaga.

II. Referensi harus dinyatakan dengan urutan sebagai berikut: penulis (s) nama, tahun publikasi, judul kertas atau buku teks, nama jurnal atau penerbit dan nomor halaman. Contoh:

a) Amerika Akuntansi Association, Komite Konsep dan Standar Laporan Keuangan Eksternal. 1977. Pernyataan tentang Teori Akuntansi dan Teori Penerimaan. Sarasota, FL: AAA.

b) Demski, J. S., dan D. E. M. Sappington. 1989. Struktur hirarkis dan akuntansi pertanggungjawaban, Jurnal Akuntansi Penelitian 27 (Spring): 40-58.

c) Dye, R. B., dan R. Magee. 1989. Biaya Kontijensi untuk perusahaan audit. Kertas kerja, Northwestern University, Evansto, IL.

d) Indriantoro, N. 1993. Pengaruh Penganggaran Partisipatif Terhadap Prestasi Kerja dan Kepuasan Kerja dengan Locus of Control dan Dimensi Budaya sebagai Moderating Variabel. Ph.D. Disertasi. University of Kentucky, Lexington.

e) Naim, A. 1997. Analisis Penggunaan Akuntansi Biaya Produk Dalam Keputusan Harga oligopolistik. Jurnal Ekonomi Dan Bisnis Indonesia 12 (3): 43-50.

f) Porcano, T. M. 1984a. Keadilan distributif dan Kebijakan Pajak. Akuntansi Ulasan 59 (4): 619-636.

g) -------. 1984b. Pengaruh Persepsi Kebijakan Pajak Niat Investasi Perusahaan. The Journal of American Association Perpajakan 6 (Fall): 719.

h) Pyndyk, R. S. dan D. L. Rubinfield. 1987. Model ekonometrik \& Forecasts Ekonomi, 3rd ed. NY: McGraw-Hill Publishing, Inc.

12. Author(s) harus melampirkan CV, alamat email, alamat korespondensi dan pernyataan yang menyatakan pasal tersebut tidak sedang disampaikan kepada atau diterbitkan oleh jurnal lain dalam email tersebut dan /atau pos. 


\title{
ANALISIS PENERAPAN METODE PENGAKUAN PENDAPATAN TERHADAP LABA PERUSAHAAN PADA PT. COCA COLA DISTRIBUSI INDONESIA (Cabang Tanjung Karang)
}

\author{
Herry Goenawan Soedarsa \\ Surya Pandelima \\ email: Herry.gs13@gmail.com \\ email: Apri_irianti@Yahoo.co.id
}

\begin{abstract}
Penjualan merupakan kegiatan yang menghasilkan pendapatan. Dimana pendapatan tersebut merupakan salah satu sumber kelangsungan hidup dari sebuah perusahaan. PT. Coca-cola Distribusi Indonesia Tanjung Karang yang merupakan perusahaan yang bergerak dalam bidang distribution minuman ringan yang mempunyai kegiatan mendistribusikan minuman ringan yang pemasarannya meliputi wilayah Lampung Tengah, Lampung Timur, Lampung Utara. PT. Coca-cola Distribution Cabang Tanjung Karang adalah perusahaan yang bergerak dalam bidang penjualan minuman ringan baik secara Tunai maupun kredit. Adapun yang menjadi permasalahan yaitu apakah metode pengakuan pendapatan yang digunakan oleh perusahaan mempengaruhi Laba dan bagaimana pengaruhnya terhadap Laporan Laba Rugi. Tujuan penelitian ini adalah untuk mengetahui bagaimana penerapan akuntansi terhadap pendapatan terhadap laporan laba rugi yang diterapkan oleh perusahaan, dan sesuai dengan kriteria dan prinsip-prinsip akuntansi yang lazim
\end{abstract}

Keywords: Analisis Penerapan, Metode Pengakuan, Laba Perusahaan

\section{Latar Belakang}

Perusahaan pada umumnya didirikan bertujuan untuk memperoleh keuntungan seoptimal mungkin, hal ini dilakukan agar kegiatan operasional dalam perusahaan dapat berjalan dengan lancar sehingga perusahaan tersebut dapat mengembangkan usahanya, guna mempertahankan keberadaan perusahaan sendiri ditengah persaingan ekonomi yang begitu ketat terutama antar perusahaan sejenis (competitor).

Laba merupakan aspek terpenting bagi perusahaan karna laba dapat digunakan sebagai alat ukur umtuk mengetahui berhasil atau tidaknya perusahaan tersebut. Laba merupakan selisih antara jumlah pendapatan dalam suatu waktu tertentu dengan beban yang terjadi pada periode tersebut. Pendapatan adalah aliran masuk aktiva yang berasal dari penyerahan barang atau jasa yang dilakukan oleh suatu unit usaha. Beban adalah pemakaian barang dan jasa dalam proses mendapatkan pendapatan. Untuk memperoleh keuntungan yang optimal dapat dilakukan dengan cara memperbesar selisih antara jumlah pendapatan dengan beban. Penerapan metode pengakuan pendapatan yang tidak tepat akan mengakibatkan penyajian yang tidak benar terhadap laporan laba rugi yang telah dibuat, karna pendapatan yang disajikan akan lebih besar (overstated) atau lebih kecil (understated). 
Tabel 1.

Pendapatan PT. Coca Cola Cabang Tanjung Karang

\begin{tabular}{|l|c|c|c|c|}
\hline No & Tahun & Penjualan Kredit & Penjualan Tunai & Total \\
\hline 1 & 2006 & 3.003 .489 .924 & 83.430 .000 & 3.086 .919 .924 \\
\hline 2 & 2007 & 3.394 .469 .800 & 159.250 .600 & 3.553 .720 .400 \\
\hline 3 & 2008 & 3.106 .005 .850 & 3.152 .921 .000 & 6.258 .926 .850 \\
\hline 4 & 2009 & 5.800 .323 .000 & 3.048 .988 .000 & 8.849 .311 .000 \\
\hline 5 & 2010 & 4.000 .326 .324 & 3.813 .854 .850 & 7.814 .181 .174 \\
\hline
\end{tabular}

Sumber: PT. Coca Cola Distribusi Indonesia Tanjung Karang

Pada penjualan tunai pendapatan yang diakui perusahaan tanpa mengalami kesulitan yang berarti, tetapi penjualan secara kredit diperlukan suatu perlakukan akuntansi atas pengakuan pendapatan. Dari proses penjualan yang dilakukan PT. Coca Cola mengakui pendapatan yang berdasarkan kontrak penjualan secara akrual, ternyata pada penerapannya perusahaan baru mengadakan pencatatan atas pendapatansaat kas diterima.

Perusahaan menetapkan bahwa pendapatan yang diakui berdasarkan kontrak penjualan secara akrual (accrual basis), sedangkan perusahaan menerapkan metode pengakuan pendapatan berdasarkan saat penerimaan kas (cash basis), maka besar kemungkinan akan terjadi perbedaan antara jumlah rupiah pendapatan yang diakui atas dasar saat penerimaan kas dan akan berpengaruh terhadap laba perusahaan. Perbedaan antara accrual basis dan cash basis sebagai berikut :

\begin{tabular}{|c|c|c|}
\hline \multirow{2}{*}{ KETERANGAN } & \multicolumn{2}{|c|}{ PERBEDAAN } \\
\hline & ACCRUAL BASIS & CASH BASIS \\
\hline $\begin{array}{l}\text { 1. Pembebanan } \\
\text { biaya }\end{array}$ & $\begin{array}{l}\text { Pada periode dimana biaya ini terjadi } \\
\text { terlepas dari kapan uang kas } \\
\text { dikeluarkan. }\end{array}$ & $\begin{array}{l}\text { Pada periode dimana biaya } \\
\text { ini dikeluarkan untuk } \\
\text { mendapatkan penghasilan }\end{array}$ \\
\hline $\begin{array}{l}\text { 2. Pendapatan dan } \\
\text { biaya yang masih } \\
\text { akan diterima } \\
\text { atau diakui }\end{array}$ & $\begin{array}{l}\text { Pendapatan akan dicatat sebagai } \\
\text { penerimaan pendapatan setelah } \\
\text { timbul hak, sedangkan biaya diakui } \\
\text { sebagai pengeluaran biaya, setelah } \\
\text { timbulnya kewajiban untuk } \\
\text { membayar tanpa suatu alas an apakah } \\
\text { pelaksanaan, penerimaan, pendapatan } \\
\text { atau pengeluaran sudah atau belum } \\
\text { terjadi. }\end{array}$ & $\begin{array}{l}\text { tunai tersebut. } \\
\text { Tidak boleh dicatat atau } \\
\text { dibukukan walaupun } \\
\text { walaupun sudah menjadi } \\
\text { hak perusahaan, sebelum } \\
\text { pendapatan dan biaya telah } \\
\text { diterima. }\end{array}$ \\
\hline $\begin{array}{l}\text { 3. Dampak } \\
\text { terhadap laba } \\
\text { rugi }\end{array}$ & $\begin{array}{l}\text { Selisis antara semua pedapatan yang } \\
\text { sudah menjadi hak perusahaan } \\
\text { dengan biaya-biaya yang harus } \\
\text { dikeluarkan karna sudah menjadi } \\
\text { kewajiban perusahaan tanpa } \\
\text { memperhatikan kapan pendapatan itu } \\
\text { diterima, kapan uang tersebut } \\
\text { dikeluarkan. }\end{array}$ & $\begin{array}{l}\text { Selisish antara pendapatan } \\
\text { yang diterima dengan tunai } \\
\text { dengan biaya-biaya yang } \\
\text { dikeluarkan untuk } \\
\text { menghasilkan pendapatan } \\
\text { tunai tersebut. }\end{array}$ \\
\hline
\end{tabular}




\begin{tabular}{|c|c|c|}
\hline $\begin{array}{l}\text { diterima, dicatat } \\
\text { sebagai } \\
\text { pendapatan } \\
\text { dengan jurnal }\end{array}$ & 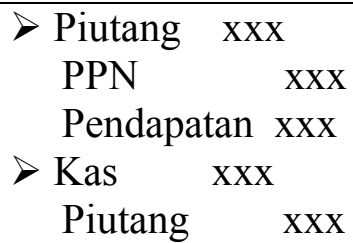 & $\begin{array}{cc}\text { Kas } & \text { xxx } \\
\text { PPN } & \text { xxx } \\
\text { Pendapatan } & \text { xxx }\end{array}$ \\
\hline
\end{tabular}

Sumber : Harahap; (2008). Teori akuntansi

\section{Landasan Teori}

\section{Konsep Dasar Pendapatan dan Laba}

Menurut IAI (2002) Pendapatan (Revenue) adalah Arus masuk Bruto dari manfaat ekonomi yang timbul dari aktivitas yang normalperusahaan selama satu periode, bila arus itu mengakibatkan kenaikan ekuitas yang tidak berasal dari kontribusi penanaman modal. Pendapatan merupakan hal yang sangat penting bagi kelangsungan usaha dalam perusahaan. Harahap (2008:2009) yang dimaksud dengan laba akuntansi adalah perbedaan antara pendapatan (revenue) yang direalisasikan yang timbul dari transaksi pada periode tertentu diharapkan dengan biaya-biaya yang dikeluarkan pada periode tersebut. Sedemikian pentingnya hubungan pendapatan dengan laba, maka penulis akan menerangkan dan menjabarkan sedikit tentang keduanya dengan literature-literatur yang ada.

\section{Pendapatan}

Konsep pendapatan mula-mula terjadi pada zaman dahulu yaitu dari barter secara sederhana berupa barang dan jasa diantara dua individu. Evolusi masyarakat dan perdagangan yang berkembang secara bertahap memegang peranan penting dalam menentukan kejadian atau transaksi yang mengakibatkan adanya arus masuk sumber-sumber ekonomi (revenue) dari mengukur nilai arus masuk tersebut dalam suatu satuan tertentu. Pada dasarnya ada 2 pandangan mengenai komponen pendapatan yaitu:

1. Pandangan Luas ( komprehensif)

Menurut pandangan ini yang dimaksud pendapatan adalah semua hasil dari aktivitas bisnis maupun aktivitas investasi. Jadi penambahan net asset karena kegiatan utama perusahaan maupun laba karena penjualan aktiva tetap dan investasi termaksud kategori ini.

\section{Pandangan Sempit}

Menurut pandangan ini yang dimaksud pendapatan adalah hanya hasil dari aktivitas perusahaan saja yang di kategorikan sebagai pendapatan. Jadi gain/losskarena penjualan aktiva tetap dan investasi tidak dikatagorikan sebagai pendapatan. 
Terhadap masalah saat penentuan pengakuan pendapatan, hendaknya tidak dibatasi oleh difinisi pendapatan yang sempit, sebagai berikut ini disajikan beberapa pengertian pendapatan. Menurut pernyataan Standar Akuntansi Keuangan (2009:23) dalam kerangka dasar penyusunan dan penyajian laporan keuangan definisi pendapatan adalah : Pendapatan adalah arus masuk bruto dari manfaat ekonomi yang timbul dari normal perusahaan selama satu periode bila arus masuk itu mengakibatkan kenaikan ekuitas, yang tidak berasal dari kontribusi penanam modal. Menurut pernyataan SAK Tahun 2009 no. 23: pendapatan dari penjualan barang harus diakui bila seluruh kondisi berikut dipenuhi :

a. Perusahaan telah memindahkan resiko secara signifikan dan memindahkan manfaat kepemilikan barang kepada pembeli.

b. Perusahaan tidak lagi mengelolah atau melakukan pengendalian efektif atas barang yang dijual.

c. Besarnya kemungkinan manfaat ekonomi yang dihubungkan dengan transaksi mengalir kepada perusahaan tersebut.

d. Biaya yang terjadi atau yang akan terjadi sehubung transaksi penjualan dapat diukur dengan andal.

e. Jumlah pendapatan tersebut dapat diukur dengan andal.”

Pengertian pendapatan disini meliputi nilai yang diukur sehubung dengan barang yang dijual dan dihasilkan yang diperoleh sebelum dikurangi oleh biaya-biaya yang timbul untuk menghasilkan pendapatan tersebut. Perhitungan revenue belum dikurangi oleh unsur-unsur biaya dalam memperoleh pendapatan tersebut. Dari uraian di atas, dapat diambil kesimpulan bahwa pendapatan pada intinya merupakan peningkatan aktivitas dari adanya arus masuk kas, piutang dan lain-lain, atau penurunan kewajiban, yang timbul dari aktivitas perusahaan sehari-hari, seperti penjualan barang atau jasa, atau pemanfaatan sumber daya perusahaan yang menghasikan bunga, royaliti dan deviden yang dapat mengubah atau mempengaruhi besar modal pemilik (owner equity).

\section{Karakter Pendapatan}

Pada dasarnya terdapat dua pendekatan terhadap konsep pendapatan (revenue) yang dapat ditemukan dalam kepustakaan akuntansi. Pada umumnya revenuetelah ditafsirkan sebagai:

1. Arus masuk net asset sebagai akibat dari penjualan barang dan jasa

2. Arus keluar barang dan jasa dari perusahaan kepada langganan produksi 
3. Perusahaan sebagai akibat dari semata-mata penciptaan barang dan jasa untuk perusahaan selama periode tertentu.

\section{Sumber-sumber Pendapatan}

Sumber pendapatan yang dikemukakan oleh Tuanakotta (1984 : 155), yang dikutip dari APB statement no. 4 mengatakan : Disamping penjualan barang atau jasa pendapatan juga meliputi penjualan sumber-sumber daya selain produk perusahaan seperti aktiva tetap dan investasi. Pada dasarnya terdapat dua pandangan mengenai pendapatan. Pendapatan yang pertama menyatakan bahwa itu meliputi seluruh hasil aktiva usaha dan dari aktiva investasi. Pandangan ini menyatakan bahwa pendapatan adalah seluruh perubahan aktiva bersih yang disebabkan oleh aktivitas penciptaan pendapatan dan keuntungan akibat penjualan aktiva tetap dan investasi. Dari pembahasan di atas dapat disimpulkan bahwa pendapatan bersumber dari :

\section{Pendapatan Operasi (operating revenue)}

Pendapatan atau revenue yang berasal dari aktivitas utama sesuai dengan perusahaan sesuai jenis usahanya, yang berlangsung secara berulang-ulang.

\section{Pendapatan Non Operasional (Non operating revenue)}

Pendapatan yang diperoleh dari transaksi modal (financing), dari laba penjualan aktiva yang bukan produk perusahaan, misalnya dari hadiah, sumbangan.

\section{Pengukuran Pendapatan}

Pendapatan dan laba harus disajikan secara wajar, tidak boleh diantisipasikan terlalu besar atau kecil. Dalam Standar Akuntansi Keuangan (PSAK) no.23 menyatakan "pendapatan harus diukur dengan nilai wajar imbalan yang diterima atau yang dapat diterima." Sedangkan cara yang terbaik untuk mengukur pendapatn menurut Tuanakotta (1984:155) adalah " Dengan menggunakan nilai tukar (exchange value) dari barang dan jasa. Nilai tukar ini merupakan cash aquevalen atau present value dari tagihan-tagihan yang diharapkan akan diterima dari transaksi pendapatan." Nilai tukar ini menunjukan kas atau nilai sekarang dari pendiskontoan tagihan uang yang akhirnya akan diterima dari transaksi pendapatan. Dalam banyak kasus, nilai tukar ini didapat dari harga yang sudah disepakati dari transaksi dengan langganan. Karna pendapatan harus dicatat secara bruto (Gross Concept), maka revenueyang berupa aktiva selain kas akan direalisasikan dengan mempertimbangkan hal-hal yang mungkin terjadi sesuai dengan transaksi penjualan.

Faktor-faktor mempengaruhi atau mengurangi pendapatan seperti potongan-potongan (trade atau cash discount), return penjualan (sale return), allowance, freight out and 
uncollectible account. Misalnya dalam penentuan berapa besarnya jumlah yang akan dicandangkan sebagai ganti rugi piutang mempunyai peranan penting untuk menetukan berapa kemungkinan yang dapat direalisasikan. Ada dua pendekatan yang dapat dilakukan untuk menetukan besarnya pendapatan yang dapat direalisasikan yaitu:

1. Revenue Statement Approach

Pendekatan ini didasarkan pada tujuan pengukuran yang wajar, yaitu ditetapkan berdasarkan presentasi penjualan. Kelemahan dari pendekatan ini adalah tidak semua penjualan dilakukan secara kredit, sedangkan yang mempunyai resiko tidak tertagihnya pendapatan dari penjualan kredit.

2. Balance Sheet Approach

Pendekatan ini ditunjukan untuk mencerminkan nilai wajar. Caranya dengan menentukan persentase tertentu terhadap saldo piutang dan melalui anging scheduleatau analisa umur piutang. Metode ini lebih wajar karena yang mempunyai resiko adalah tagihan yang belum dilunasi. Factor umur tagihan turut pula dipertimbangkan, dimana semakin panjang umur tagihan maka sebagian besar persentase kemungkinan tidak tertagihnya piutang.

\section{Pengakuan Pendapatan}

Pengakuan pendapatan (Revenue Recognition) merupakan salah satu elemen dasar dari kerangka acuan konseptual (Conseptual Framework). Karena adanya perbedaan yang signifikan dalam praktek pada berbagai macam jenis usaha, sebagai kerangka ini dianggap sebagai salah satu yang paling sulit dipecahkan. Pendapatan direalisasikan pada saat produk (barang dan jasa), barang dagangan atau aktiva lainya ditukang dengan uang tunai atau suatu aktiva klaim untuk memperoleh uang/kas tersebut.

\section{Metode Pengakuan Pendapatan}

Berbagai metode pendapatan banyak diterapkan dalam dunia usaha, namun sebagai ketentuan umum, pendapatan diakui pada saat realuisasinya. Prinsip tersebut dijabarkan metode yaitu :

\section{Metode pengakuan pendapatan pada saat selesai produksi}

Pengakuan pendapatan setelah sesuai produksi dapat diterapkan jika perusahaan dapat menentukan besarnya harga pasar dan biaya pemasaran secara tepat. Kedua masalah tersebut dapat diketahui oleh perusahaan, apabila perusahaan dengan pembelian sebelum barang tersebut selesai diproduksi. Jika membeli melakukan pembayaran pada perjanjian atau kontrak penjualan dilakukan maka penerimaan uang tersebut tidak boleh dianggap sebagai pendapatan sampai barang tersebut selesai diproduksi. Suatu penjualan yang tidak 
berdasarkan kontrak atau perjanjian dapat diakui sebagai pendapatan setelah selesai produksi apabila memenuhi syarat-syarat dibawah ini :

a. Harga pasar dari barang tersebut stabil dan telah selesai

b. Biaya penjualan tersebut tidak besar

c. Barang tersebut mudah dipasarkan

\section{Metode Pengakuan Selama Proses Produksi}

Dalam keadaan tertentu, pendapatan lebih berarti jika dilaporkan sebelum pengiriman barang (penjualan), atau sebelum produksi selesi maupun sebelum semua jasa dilakukan, keadaan ini biasanya timbul bila periode dari jasa yang dilakukan relative panjang(lebih dari satu periode). Jika perusahaan menunggu untuk melaporkan pendapatan sampai kontruksi atau jasa selesai dilakukan, maka laporan laba rugi yang dibuat dalam periode barang dan jasa selesai, tidak akan menunjukan perkembangan perusahaan sama sekali dan tidak akan memberikan informasi apapun, baik bagi manajemen maupun pihak lain.

\section{Metode pengakuan pendapatan untuk kontrak jangka panjang}

Metode ini dibuat terutama untuk pengakuan pendapatan bagi suatu perusahaan kontraktor yang melaksanakan pembangunan rumah atau gedung, jalan, jembatan, instalasi, kontrak untuk pembangunan penerbangan militer atau komresial, dimana tanggal dimulai konruksi dan tanggal selesai pekerjaan jatuh pada periode akuntansi yang berbeda (long term contruction), yang penerapannya sebagai berikut :

\section{Metode persentase penyelesaian}

Menurut salah satu divisi dari AICPA yang mengeluarkan statement accounting for performance of contruction - type dan certain production-type contracts, syarat-syarat yang harus dipenuhi dalam menggunakan metode persentase penyelesaian adalah :

1. Dapat dibuat penafsiran yang dapat dipertanggungjawabkan atas kemajuan pekerjaan, penghasilan kontrak, biaya kontrak.

2. Kontrak harus secara jelas menyebutkan hak-hak yang harus ditegaskan dalam barang dan jasa yang akan diserahkan dan diterima oleh pihak-pihak yang bersangkutan, pertimbangan yang harus diputuskan dalam syarat-syarat pelaksanaan kontrak.

3. Pembelian dapat diharapkan untuk memenuhi kewajiban berdasarkan kontrak.

4. Kontraktor atau perusahaan dapat diharapkan untuk melakukan kewajiban-kewajiban kontraknya.

Keuntungan yang diperoleh dari penggunaan metode persentase penyelesaian : 
1. Pendapatan dilaporkan secara periodic sesuai dengan kemajuan pekerjaan yang telah diselesaikan, sehingga dapat dilakukan matching antara pendapatan dan biaya pada periode tersebut.

2. Kontrak yang belum diselesaikan dapat dicari keuntungan berdasarkan taksiran.

Kelemahan dari metode persentase penyelesaian yaitu :

1. Penentuan total biaya sulit diperkirakan sebelumnya, karna faktor uncertainties dari biaya yang belum terjadi atau biaya masa akan dating

2. Membutuhkan kontrak yang cukup akurat dan jelas dalam hak-hak dan kewajiban pihak-pihak yang terlibat.

3. Metode berdasarkan logika bahwa pendapatn timbul karena adanya biaya yang telah dikeluarkan, sedangkan kegiatan yang penting mungkin terjadi pada tingkat perencanaan dimana belum ada biaya yang material dikeluarkan.

4. Keharusan membuat cadangan untuk kemngkinan rugi atau gagalnya dalam memenuhi kontrak.

\section{Metode Kontrak Selesai (completed contract method)}

Metode ini tidak termaksud kelompok yang mengakui pendapatan selama produksi, metode ini hanya merupakan alternative jika metode persentase tidak dapat dipakai lagi. Metode ini digunakan jika:

1. Kontraknya jangka pendek.

2. Syarat-syarat yang diajukan oleh divisi AICPA dan standar akuntansi keuangan diatas tidak dapat dipenuhi

3. Kadar ketidak pastian kontrak melebihi resiko bisnis yang normal.

Menurut metode ini pendapatan diakui pada saat kontrak atau proyek telah selesai dilaksanakan dan diserakan kepda pembeli. Ini berarti bahwa laba atau rugi tersebut tidak dapat dihitung selama proyek masih berjalan, walaupun pembayaran kas sudah dapat diterima dari pihak pembeli. Keuntungan menggunakan metode kontrak adalah:

a. Hasil operasi perusahaan tidak dilaporkan secara berkala, sehingga menyulitkan bagi pemakai laporan keuangan untuk mengambil keputusan.

b. Metode ini gagal menerapkan periodical matching cost with revenue.

c. Adanya kecenderungan untuk memasukan emua biaya timbul dalam contruction in progress account atau rekening perediaan, walaupun biaya penjualan (selling), umum (general), dan administrasi yang sebenarnya tidak berhubungan langsung dengan 
kontruksi untuk menghindari laporan rugi laba negative karna tidak adanya pendapatan yang diakui.

\section{Metode Pengakuan Pendapatan Diakui Pada Saat Pembayaran Diterima}

Pencatatan pada saat penerimaan kas, sering dilaksanakan pada perusahaan jasa yaitu jasa yangdiserahkan dalam jangka waktu yang pendek seperti yng terjadi pada perusahaan pengangkatan, hiburan dan lain-lain. Oleh karna itu, biasanya pembayaran dari langganan terjadi pada saat jasa diserahkan. Keadaan lain yang menyebabkan penggunaan metode ini adalah :

1. Jika aktiva yang diterima sebagai pembayaran produk yang diserahkan tidak dapat diukur secara tepat. Misalnya pembayaran dalam bentuk aktiva berwujud, maka harus ditunda dahulu sampai aktiva tersebut dijual.

2. Jika masih ada biaya-biaya yang material jumlahnya yang masih dikeluarkan dan biayabiaya ini tidak dapat ditafsirkan jumlahnya secara tepat.

\section{Metode Pengakuan Pendapatan Pada Penjualan}

Teknis pembuatan pendapatan ini adalah jenis yang banyak dilakukan dalam dunia usaha dibandingkan dengan metode pengakuan pendapatan lainnya, hal ini disebabkan karna beberapa factor yaitu :

1. Pada saat penjualan harga produk dapat diterapkan dengan pasti dan telah terjadi pertukaran produk dengan aktiva (asset) yang baru dimana pertukaran ini dapat dianggap sebagai bukti realisasi.

2. Pada saat penjualan, dalam hal ini yang normal dari pendapatan yang dapat ditentukan secara obyektif dari harga penjualan yang disetujui oleh pihak pembeli dan penjual.

3. Kepastian terhadapa jumlah biaya yang berhubungan dengan produk yang bersangkutan telah terjadi dengan adanya penyerahan barang.

\subsection{Pengertian Laba}

Pengakuan pendapatan (revenue) dikemukan di dalam Standar Akuntansi Keuangan (2009:23) adalah Pendapatan diakui dalam laporan rugi laba kalau kenaikan manfaat ekonomi dimasa yang akan mendatang yang berkaitan dengan peningkatan aktiva atau penurunan kewajiban terjadi dapat diukur dengan andal. Ini berarti pengakuan penghasilan terjadi bersamaan dengan pengakuan kenaikan aktiva atau penurunan kewajiban (misalnya, kenaikan aktiva bersih aktiva yang timbul dari penjualan barang atau jasa atau penurunan 
kewajiban dari pembebasan pinjaman yang masih harus dibayar). Dlihat dari pendapatan yang diterima laba dibagi menjadi dua yaitu:

a. Laba yang sudah direalisasi, yaitu laba yang sudah diakui pada saat transaksi.

b. Laba yang belum direalisasi, yaitu laba yang sudah terjadi karna pertambahan kekayaan yang disebabkan oleh kenaikan aktiva, artinya tidak terjadi adanya pertukaran laba

Ada dua pendekatan untuk mengukur revenue yaitu:

1. Pendekatan Ekonomi (Economic Approach)

Pendekatan ekonomi dalam menilai laba adalah menilai harta bersih dari satuan usaha pada dua waktu yang berbeda dan menghitung perubahan yang telah terjadi.

2. Pendekatan Transaksi (Transaction Approach)

Metode ini sering disebut dengan metode penandingan (matching method). Dimana pendapatan terus dibandingkan dengan biaya yang terjadi untuk menghasilkan laba. Perbedaan pada kedua unsur ini diakui sebagai laba bersih (Net Revenue) .

Keuntungan dari pendekatan ini adalah

1. Komponen-komponen atau unsur net revenue dapat diklasifikasikan dengan beberapa cara .

2. Revenue yang berasal dari beberapa sumber pendapatan seperti operasi perusahaan dan dari sebab ekstern, dapat dilaporkan secara terpisah, apabila sumber-sumber yang berbeda dapat diukur.

3. Pendekatan ini memberikan dasar bagi penetapan jenis dan jumlah asset dan liabilities pada akhir suatu periode.

4. Efisiensi perusahaan merupakan pencatatan transaksi-transaksi ektern bagi keperluankeperluan ini.

5. Berbagi ikhtisar keuangan dapat dikaitkan satu sama yang lainnya.

Selanjutnya penulis akan memberikan penjelaan tentang dua metode pencatatan pendapatan yaitu metode cash basis dan metode accrual basis dalamkaitannya dengan perhitungan laba rugi perusahaan, yaitu :

1. Cash basis method

Dengan dasar cash basis, penghasilan-penghasilan dari penjualan barang atau jasa dianggap dapat diperoleh pada waktu dikumpulkan per kas dari langganan, dan biayabiaya diangap dikeluarkan atau diakui jika telah digunakan untuk pembayaran perlengkapan, barang,jasa dan item-item operasi lainnya.

2. Accrual Basis Method 
Dengan dasar akrual, penghasilan-penghasilan tersebut diperoleh terlepa dari kapan pembayaran-pembayaran diterima dan biaya-biaya dibebankan pada periode dimana biaya-biaya itu terjadi terlepas dari kapan uang kas dikeluarkan.

\subsection{Penelitian Terdahulu}

1. David N Hurtt (2008)

Melakukan penelitian yang diuraikan secara garis besar penelitian ini tentang "Evaluasi pengakuan pendapatan ketika adanya retur" dalam penelitian ini masalah yang diambil bagaimana laporan perusahaan akan melaporkan pendapatan ketika adanya pengembalian atas kerusakan produk. Maka metode yang digunakan yaitu pengakuan pendapatan pada saat penjualan.

2. Marpaung (2006)

Penelitian yang digunakan secara garis besar penelitian ini tentang pengakuan pendapatan pada RS. X dalam penelitian ini masalah yang diambil penerapan dalam hal pendapatan jasa, metode penelitiannya menggunakan tekhnik pengumpulan data berupa wawancara serta data primer sehingga menggunakan metode kualitatif.

\subsection{Kerangka Pemikiran}

\begin{tabular}{|l|l|} 
METODE PENGAKUAN \\
\cline { 2 - 3 } \\
PENDAPATAN $(\mathrm{X})$ \\
1. Pengakuan dengan Metode Accrual Basis \\
2. Pengakuan Akuntansi Pengakuan \\
Pendapatan
\end{tabular}

LABA PERUSAHAAN (Y)

1. Laba yang sudah direalisasi

2. Laba yang belum direalisasi

Dikembangkan dari : (Firdaus, 2001)

Sumber : $\operatorname{SAK}(2009: 23)$

\section{Metode Penelitian}

\subsection{Objek penelitian}

Penelitian ini dilaksanakan di Sales office PT. Coca-Cola Distribusi Indonesia Cabang Tanjung Karang. Data yang digunakan dalam penelitian ini yaitu data penjualan, biaya operasi, dan laba operasi dari tahun 2006 sampai dengan 2010 dan data-data pendukung 
lainnya dianggap penulisan dibutuhkan dalam penelitian ini. Waktu penelitian dilakukan pada bulan november 2013 hingga selesai.

\subsection{Jenis Pengumpulan Data}

- Data sekunder

Data sekunder adalah data yang bukan diusahakan sendiri pengumpulannya oleh peneliti sendiri. Datanya yang diperoleh antara lain adalah :

1. Gambaran Umum Perusahaan

2. Data Laporan Keuangan

\subsection{Metode Pengumpulan Data}

- Observasi

Untuk memperoleh gambaran pengertian dan lain-lain yang diobservasi. Teknik observasi yang digunakan adalah secara lansung, yaitu dengan menggunakan pengamatan secara langsung terhadap obyek penelitian secara langsung dilapangan.

\subsection{Teknik Analisis}

- Analisis Deskriptif

Analisis ini dilakukan untuk menganalisis data dengan cara mendeskripsikan atau mengambarkan data yang telah diolah.

\section{Pembahasan dan Analisis}

\subsection{Pencatatan Akuntansi}

Dalam sistem pembukuan PT. Coca Cola Cabang Lampung, transaksi yang terjadi dicatat dalam suatu buku yang lazim disebut sebagai buku jurnal. Buku jurnal tersebut merupakan buku catatan awal (book of original entry) dan bukti dasar berupa akuntansi, faktur atau dokumen-dokumen lainnya. Bukti - bukti dasar tersebut merupakan siklus awal dalam siklus akuntansi, mempunyai kegunaan sebagai berikut:

1. Sebagai dasar untuk mencatat semua kegiatan usaha perusahaan.

2. Sebagai alat untuk mempelancar teknis pelaksanaan kegiatan.

3. Sebagai alat untuk melakukan perhitungan-perhitungan.

4. Sebagai alat untuk melakukan pengawasan. 
Perusahaan mempunyai empat buku jurnal khusus yaitu buku pembelian, buku pengeluaran kas, buku penjualan dan buku penerimaan kas.

\subsection{Penerapan Metode Pengakuan Pendapatan}

Adapun sistem pembayaran disini tidak terdapat denda, karna hasil dari penjualan seperti warung, ruko, mini market dan lainnya sudah mempunyai kesepakatan, tanggung jawab dan kepercayaan untuk membayar uang muka sebagai jaminannya atau deposit. Jurnal pada saat pembayaran diterima dari hasil penjualan akibat diterbitkannya surat tagihan oleh perusahaan.

1. Jurnal pada saat barang terjual dan belum terbayarkan Piutang XXX Penjualan $\operatorname{xxx}$

2. Jurnal pada saat pelunasan pembayaran Kas Piutang $\mathrm{XXX}$ $\operatorname{xxx}$

Karakteristik kualitatif merupakan ciri khas yang membuat informasi dalam laporan keuangan berguna bagi pemakai. Terdapat empat karakteristik kualitatif pokok, yaitu :

1. Dapat dipahami

2. Relevan

3. Keandalan

4. Dapat diperbandingkan

Sedangkan dalam buku Baridwan,(2004) Akuntansi Keuangan Menengah, agar suatu informasi akuntansi baik akurat tepat waktu dalam memberikan manfaat bagi para pemakainya, terdapat beberapa syarat utama dalam informasi akuntansi. Informasi keuangan akan bermanfaat bila dipenuhi ketujuh kualitas berikut :

1. Relevan

Relevansi suatu informasi harus dihubungkan dengan maksud penggunanya. Bila informasi tidak relevan untuk keperluan para pengambilan keputusan, informasi demikian tidak akan ada gunanya, betapa pun kualitas-kualitas lainnya terpenuhi.

2. Dapat Dimengerti

Informasi harus dapat dimengerti oleh pemakainya, dan dinyatakan dalam bentuk dengan istilah yang sesuaikan dengan batas pengertian para pemakai. Dalam hal ini dari pihak-pihak pemakai juga diharapkan adanya pengertian/pengetahuan mengenai aktivitas-aktivitas ekonomi perusahaan, proses akuntansi keuangan, dan sebagainya.

3. Daya Uji 
Pengukuran tidak dapat sepenuhnya lepas dari pertimbangan-pertimbangan dan pendapatan yang subjektif. Hal ini berhubungan dengan keterlibatan manusia didalam proses pengukuran dan penyajian informasi, sehingga proses tersebut tidak lagi berlandaskan pada realita objektif semata.

4. Netral

Informasi harus diarahkan pada ketentuan umum pemakai, dan tidak bergantung pada kebutuhan dan keinginan pihak-pihak tertentu. Tidak boleh ada usaha untuk menyajikan informasi yang mnguntungkan beberapa pihak, sementara hal tersebut akan merugikan pihak-pihak lain yang menpunyai kepentingan yang berlawanan

5. Tepat Waktu

Informasi yang harus disampaikan sedini mungkin untuk dapat digunakan sebagai dasar untuk membantu dalam pengambilan keputusan-keputusan ekonomi dan untuk menghindari tertundanya pengambilan keputusan tersebut.

6. Daya Banding

Informasi dalam laporan keuangan akan lebih berguna bila dapat dibandingkan dengan laporan keuangan periode sebelumnya dari perusahaan yang sama, maupun dengan laporan keuangan perusahaan-perusahaan lainnya pada periode yang sama

7. Lengkap

Informasi akuntansi yang lengkap meliputi semua data akuntansi keuangan yang dapat terpenuhi secukupnya enam tujuan kualitatif diatas dapat juga diartikan sebagai standar pengungkapan yang memadai dalam pelaporan kaungan.

\subsection{Penerapan Metode Pengakuan Pendapatan yang diterapkan PT. Coca-Cola Distribusi Indonesia ( Cabang Tanjung Karang)}

Menurut Juanda: (2001) bahwa ada empat metode pengakuan pendapatan yaitu :

1. Metode Pengakuan Pendapatan Selama Produksi

2. MetodePengakuan Pendapatan pada saat selesai produksi

3. Metode Pengakuan Pendapatan diakui pada saat Pembayarn diterima

4. Metode Pengakuan Pendapatan pada saat penjualan.

Dari keempat metode pengakuan diatas bahwa PT. Coca-cola Distribusi Indonesia cabang tanjung karang hanya menggunkan satu metode yaitu metode pengakuan pendapatan pada saat penjualan. Teknik Metode ini memiliki fitur pencatatan dimana transaksi dimana transaksi sudah dapat dicatat karena transaksi tersebut memiliki implikasi uang masuk atau keluar dimasa depan. Transaksi dicatat pada saat terjadinya walaupun uang belum benar- 
benar diterima atau dikeluarkan. Dengan kata lain accrual basis digunakan untuk pengukuran aset, kewajiban dan ekuitas dana. Jadi accrual basisakuntansi yang mengakui pengaruh transaksi dan peristiwa lainnya pada saat transaksi dan peristiwa itu terjadi tanpa memperhatikan saat kas atau setara kas diterima atau dibayar.

Dalam metodeaccrual basis, perusahaan mencatat semua pendapatan yang harus diterima tanpa memperhatikan kapan pembayaran atau pendapatan tersebut diterima kasnya, serta membebankan semua biaya pada periode dimana biaya ini terlepas dari kapan uang kas dikeluarkan. Pendapatan diakui sebagai penerimaan pendapatan setelah terjadinya timbulnya hak dan biaya diakui sebagai pengeluaran biaya setelah timbulnya kewajian untuk membayar tanpa suatu alasan apakah pelaksanaan penerimaan pendapatan atau pengeluaran sudah atau belum terjadi. Maka perusahaan akan mencatat pendapatan dengan jurnal sebagai berikut :

Piutang

$\mathrm{xxX}$

Penjualan $\mathrm{xxx}$

Dengan metode ini, fluktuasi laba rugi menjadi tidak stabil, karna pendapatan yang diakui pada akhir periode tersebut tidak semua terealisasi sesuai dengan sales contract. Ini tercermin dalam data-data yang ada dalam perusahaan. Kemungkinan tidak terealisasinya pendapatan yang diakui oleh perusahaan cukup besar, karna sejak awal perusahaan telah mengakui pendapatan tersebut sebagai piutang, maka piutang kontrak akan terakui cukup tinggi. Untuk menyesuaikan pendapatan yang benar-benar terealisasi dengan pendapatan yang telah dicatat, perusahaan harus mengadakan koreksi terhadapnya. Accrual basis sesuai dengan konsepnya dalam penerapannya mengacu pada :

1. Pengakuan Pendapatan

Saat pengakuan pendapatan pada accrual basis adalah pada saat perusahaan mempunyai hak untuk melakukan penagihan dari hasil kegiatan perusahaan. Dalam konsep accrual basis menjadi hal yang kurang penting mengenai kapan kas diterima. Makanya dalam accrual basis kemudian muncul adanya estimasi piutang tak tertagih, sebab penghasilan sudah diakui pada hal kas belum diterima.

2. Pengakuan Biaya

Pengakuan biaya dilakukan pada saat kewajiban membayar sudah terjadi, sehingga dengan kata lain, pada saat kewajiban membayar sudah terjadi, maka titik ini dapat dianggap sebagai starting point munculnya biaya meskipun biaya tersebut belum dibayar. Dala era bisnis dewasa ini, perusahaan selalu dituntut untuk senantiasa menggunakan konsep accrual basis ini. 
Dilihat dari laporan Laba Rugi bahwa perusahaan menggunakan metode accrual basis dapat ditunjukan dalam laporan laba rugi pada halaman berikut:

Laporan laba rugi perusahaan dengan Metode Pengakuan Pendapatan pada Penjualan

PT. COCA COLA DISTRIBUSI INDONESIA

CABANG TANJUNG KARANG

LAPORAN LABA RUGI

PER 31 DESEMBER 2010

Pendapatan Operasi

5.990 .883 .150

Biaya Operasi

Biaya Pegawai

Biaya Bahan

240.335 .000

255.760 .000

253.560 .000

875.005 .000

Biaya Penyusutan

260.030 .000

45.000 .000

54.760 .050

255.882 .000

Biaya Adm. Kantor

Biaya Umum

$(3.210 .333 .050)$

2.780 .550 .000

Laba Rugi Operasi

1.950 .498 .898

730.772 .574

- Biaya diluar usaha

Selisih Pendapatan dan Biaya diluar Usaha

Laba Rugi sebelum pajak

$\frac{1.219 .776 .324}{4.000 .326 .324}$

Laba dengan Perhitungan secara Accrual basis

HASIL PENJUALAN MINUMAN RINGAN

TAHUN 2012

(diterima secara kredit)

\begin{tabular}{|l|r|}
\hline \multicolumn{1}{|c|}{ BULAN } & LABA PROFIT \\
\hline JANUARI & 100,473350 \\
\hline FEBRUARI & $200,949,224$ \\
\hline MARET & $300,984,300$ \\
\hline APRIL & $300,884,100$ \\
\hline MEI & $309,335,200$ \\
\hline JUNI & $354,773,000$ \\
\hline JULI & $536,585,200$ \\
\hline AGUSTUS & $376,802,550$ \\
\hline SEPTEMBER & $364,400,850$ \\
\hline OKTOBER & $330,281,000$ \\
\hline
\end{tabular}




\begin{tabular}{|l|r|}
\hline NOVEMBER & $400,342,850$ \\
\hline DESEMBER & $421,514,700$ \\
\hline & $4,000,326,324$ \\
\hline
\end{tabular}

Dari uraian yang dikemukakan diatas dapat disimpulkan bahwa pencatatan akuntansi dengan metode accrual basis mempunyai keunggulan dan kelemahan sebagai berikut:

1. Keunggulan pencatatan akuntansi secara Accrual

a. Metode accrual basis digunakan untuk pengukuran aset, kewajiban dan ekuitas dana

b. Beban diakui terjadi pada saat terjadi transaksi, sehingga informasi yang diberikan lebih andal an terpercaya.

c. Pendapatan diakui pada saat terjadinya transaksi, sehingga informasi yang diberikan lebih handal dan terpercaya walaupun kas belum diterima.

d. Banyak digunakan oleh perusahaan perusahaan besar (sesuai dengan ketentuan standar akuntansi keuangan dimana mengharuskan suatu perusahaan untuk menggunkan accrual basis

e. Piutang yang tak tertagih tidak akan dihapus secara langsung tetapi akan dihitung kedalam estimasi piutang tak tertagih.

f. Adanya pembentukan pencadangan untuk kas yang tak tertagih, sehingga dapat mengurangi resiko kerugian.

2. Kelemahan pencatatan akuntansi secara accrual basis

a. Metode Accrual Basis digunakan untuk pencatatan

b. Biaya yang belum dibayar secara kas, akan dicatat efektif sebagai biaya sehingga dapat mengurangi pendapatan perusahaan.

c. Adanya resiko pendapatan yang tak tertagih sehingga dapat membuat mengurangi pendapatan perusahaan

d. Dengan adanya pembentukan cadangan akan dapat mengurangi pendapatan perusahaan

e. Perusahaan tidak mempunyai perkiraan yang tepat kapan kas yang belum dibayar oleh pihak lain dapat diterima.

\section{Kesimpulan dan Saran}

\subsection{Kesimpulan}

Dari hasil penelitian yang telah dilakukan oleh penulis dapat ditariksuatu kesimpulan sebagai berikut : 
1. Metode pengakuan pendapatan yang digunakan PT. Coca Cola Distribusi Cabang Bandar Jaya sudah tepat dalam penerapannya dan dapat menunjukan kondisi laba secara baik

2. Dilihat dari laporan laba rugi menggunakan metode pengakuan pendapatan yang digunakan perusahaan sudah baik, dimana perusahaan sudah menerapkan metode Accrual Basis, dan laba yang dihasilkan pun cukup besar.

3. Akunansi berbasis accrual berarti suatu basis akuntansi dimana transaksi ekonomi peristiwa-peristiwa lain diakui dan dicatat dalam catatan akuntansi dan dilaporan dalam periode laporan keuangan pada saat terjadinya transaksi tersebut, bukan pada saat kas diterima atau dibayar. Akutansi berbasis accrual ini banyak dipakai oleh institusi sektor non publik dan lembaga lain yang bertujuan mencari keuntungan.

\subsection{Saran}

Berdasarkan pembahasan dan kesimpulan tersebut diatas maka penulis mengajukan saran sebagai berikut :

1. Metode Pengakuan Pendapatan yang diterapkan perusahaan sudah tepat dan sesuai dengan peraturan SAK

2. Accrual basis sudah menjadi dasar dalam penyusunan laporan keuangan bagi semua entitas yang menggunakan SAK umum, SAK ETAP, ataupun SAK SYARIAH. Untuk itu disarnkan pada perusahaan afar selalu menyesuaikan penerapan metode tersebut dengan aktivitas perusahaan.

3. Pengendalian terhadap penagihan piutang perlu ditingkatkan, agar kemungkinan terjadinya piutang tak tertagih dapat ditekan seminimal mungkin.

\section{Daftar Pustaka}

Harahap, Sofyan Syafri. 2008. Teori Akuntansi. PT. Raja Grafindo Persada. Jakarta.

Baridwan,Zaki. 1997. Intermediate Accounting. Edisi 7. Yogyakarta: BPFE.

Ikatan Akuntansi Indonesia.2001. Standar Profesional Akuntan Publik. Salemba Empat. Jakarta.

Ikatan Akuntansi Indonesia. 2002. Standar Akuntansi Keuangan. Salemba Empat. Jakarta.

Firdaus, Juanda, 2001, Analisis Metode Pengakuan Pendapatan dalam Hubungan dengan Laporan Laba Rugi. Skripsi Universitas Bandar Lampung, Lampung.

Hendrikson, Eldon S. 1997. Teori Akuntansi . Edisi ke-4 Penerbit Erlangga. Jakarta.

Undang-Undang RI No. 28 tahun 2009 tentang Pajak Daerah dan Retribusi Daerah.

Undang-Undang RI No. 32 tahun 2004 tentang Pemerintahan Daerah.

Wiyono, Gendro. 2011. Merancang Penelitian Bisnis. UPP STIM YKPN. Yogyakarta. 